\title{
Predictive Relationships Between Social Anxiety, Internet Addiction and Alexithymia in Adolescents
}

\author{
Cagla Girgin Buyukbayraktar ${ }^{1}$ \\ ${ }^{1}$ Ali Akkanat Applied Science School, Selcuk University, Beysehir, Konya, Turkey \\ Correspondence: Cagla Girgin Buyukbayraktar, Ali Akkanat Applied Science School, Selcuk University, \\ Beysehir, Konya, Turkey. E-mail: caglagirgin@selcuk.edu.tr
}

Received: January 22, 2020 Accepted: March 4, 2020 Online Published: March 10, 2020

doi:10.5539/jel.v9n2p222 URL: https://doi.org/10.5539/jel.v9n2p222

\begin{abstract}
The purpose of this study is to determine whether social anxiety predicts internet addiction and alexithymia in adolescents. The study group of the study consists of 406 adolescents ( 216 women, 190 men), with the following three age groups: 13-14 (32.3\%), 15-16 (43.8\%), and 17-18 (23.9\%). "Social Anxiety Scale for Adolescents (ESCO)", "Internet Addiction Scale", "Toronto Alexithymia Scale" and "Personal Information Form" were used as data collection tools. Structural equation modeling was made in the analysis of the data. According to the findings, there was a positive linear relationship between social anxiety and internet addiction. When the predictive relationships between social anxiety and alexithymia were examined, it was determined that there was a positive linear relationship. The findings were discussed in the light of the relevant literature.
\end{abstract}

Keywords: social anxiety, internet addiction, alexithymia, adolescents

\section{Introduction}

Adolescence is an intermediate period between childhood and adulthood (Kulaksizoglu, 2004, p. 32), a transition is a period of change (Severin, 2000, p. 17). It is more appropriate to consider adolescence as a development that spreads to a certain period rather than a phenomenon that occurs after a certain event (Temel \& Aksoy, 2001). In the normal development process, it is natural that some problems exist in adolescents (Eksi, 2003). With the transition to adolescence, the child takes on new roles socially, turns to new patterns of relationship and becomes part of his culture (Erwin, 2000, p. 80). These new roles may create some social concerns in adolescents.

Emotions of adolescents show rapid ups and downs, from happiness to sadness and anger (Yorukoglu, 2006, p. 375). Adolescents whose emotions are variable should be able to express their feelings not only with what they do but also with their words (Orvin, 1997, p. 86). Alexithymia causes inadequate regulation of emotional and physical responses to sensations (De Berardis et al., 2008). This causes individuals with alexithymia to show poor social functionality during social situations (Moriguchi et al., 2009; Bird, Silani, Brindley, White, Frith, \& Singer, 2010).

Most of the adolescents use the internet every day (Moll, 2003; Norris, 2007). The concept of 'Net Generation' is used to determine the broad effects of the internet on today's youth (Liu, 2010). Internet addiction is an impulse control disorder characterized by the inability to prevent internet use (Cheng \& $\mathrm{Li}, 2014$ ).

Individuals who show significant alexithymia in their adolescence often have difficulties in socializing and thus feel discomfort in social situations, which may make them more susceptible to social anxiety (Kaur \& Kaur, 2015). Individuals who are socially anxious may prefer communication over the internet instead of face-to-face communication. At the same time, individuals with social anxiety may have difficulties in recognizing the feelings of others (O'Toole, Hougaard, \& Mennin, 2013). From this point of view, it was aimed to reveal the direct relationships of social anxiety on internet addiction and alexithymia.

\subsection{Social Anxiety}

Social affirmation is among the strongest fears of people (Schlenker \& Leary, 1982). Adolescence is a period of rapid development in social interaction (Dahl, 2004) and social anxiety is a common disorder that occurs in adolescence (Wittchen \& Fehm, 2003), which follows a chronic course if not treated (Donovan, 2014; Hayward, Wilson, Lagle, Kraemer, Killen, \& Taylor, 2008). Social anxiety in adolescents; their close relationships with peers can cause adolescents' social regression and behavioral disabilities that may weaken their ability to shape 
success (La Greca \& Lopez, 1998).

Social anxiety is particularly disruptive when it involves fears about social situations (Kessler, Stein, \& Berglund, 1998; Morrison \& Heimberg, 2013). Social anxiety disorder is a tendency to avoid interactions or situations (Blanco, Bragdon, Schneier, \& Liebowitz, 2013; Kessler, Chiu, Demler, \& Walters, 2005). Individuals with social anxiety physical and motor symptoms; they experience the fear of being observed by others such as flushing, chills, sweating and speech barriers (Bogels et al., 2010).

\subsection{Alexithymia}

Alexithymia is a psychological concept that indicates the difficulty of identifying and communicating emotions (Campanella et al., 2012; Conrad, Schilling, Langenbuch, Haidl, \& Liedtke, 2001; Franz et al., 2008; Motan \& Gencoz, 2007; Ricciardi, Demartini, Fotopoulou, \& Edwards, 2015). Alexithymia is a term that describes the distortions in one's own knowledge of emotions (Lane, Sechrest, Riedel, Shapiro, \& Kaszniak, 2000; Nemiah, 1977; Taylor \& Bagby, 2012), which speaks of the emotional arousal of emotional arousal, the lack of fantasies and the difficulty in distinguishing it from an overly concrete way of thinking (Lesser, 1981; Sifneos, 2000).

Individuals with alexithymia cannot define their emotions and cannot determine the causes of their emotional responses (Lumley, 2004; Speranza, Loas, Wallier, \& Corcos, 2007), they lack imagination and may show behaviorally attenuated effects (Campanella et al., 2014; Vorst \& Bermond, 2001). In addition, patients with alexithymia show high alexithymia and low social support characteristics (Geenen, van Ooijen-van der Linden, Lumley, Bijlsma, \& van Middendorp, 2012). Since Alexithmic individuals are cold and distant, the lack of interpersonal relationships can cause problems in their social lives (Goerlich-Dobre, Witteman, Schiller, van Heuven, Aleman, \& Martens, 2014; Vanheule, Desmet, \& Meganck, 2007). Alexithymic individuals show emotional awareness and communication deficiencies (Lumley, Neely, \& Burger, 2007). Alexithymia consists of four main elements: difficulty in identifying and explaining emotions; limited creative processes; avoiding the tendency to act to resolve contradictions; and difficulty in making a detailed description of facts, events and physical symptoms (Taylor, 2000).

\subsection{Internet Addiction}

The concept of internet addiction was first introduced by Young (1996). Various concepts such as pathological internet use (Davis, 2001), problematic internet use (Davis, Flett, \& Besser, 2002) have been used to describe this behavior. The internet is a highly used technological tool and it is difficult to detect addiction. Therefore, it is important to understand the criteria that distinguish normal from pathological internet use (Young, 2004).

Problematic internet use or internet addiction are excessive or poorly controlled concerns, urges, or behaviors that cause trouble with internet use (O'Reilly, 1996; Weinstein \& Lejoyeux, 2010). Internet addiction can be conceptualized as an incompatible model of internet use behavior associated with various psychological and social problems (Chou, Condron, \& Belland, 2005), the inability of the individual to control the internet use causes sadness and functional disruption of daily activities (Sato, 2006; Shapira et al., 2003). Dependency, according to experts, must harm various levels of function, such as family, social, school, professional and psychological functionality (Gentile, 2009). It also consists of a heterogeneous range of internet activities with potential disease value, such as gaming, shopping, gambling, or social network (Kuss \& Griffiths, 2012).

Internet for young people; It offers opportunities such as e-mail, chat, discussion group, social entertainment (games, songs, videos) and so on (Chou \& Hsiao, 2000). In addition, the internet has negative effects and these effects can create an isolating environment that leads to loneliness and less social interaction with family members and friends (Turkle, 1996). Adolescents constitute the biggest target group related to the negative effects of internet addiction (Chou, Condron, \& Belland, 2005). There are studies indicating that the prevalence of internet addiction among high school students is high (Sasmaz et al., 2013).

One of the reasons why adolescents are internet addicts is that the internet provides the opportunity to access many Web sites and communicate with various friends by meeting personal needs with personal computers (Yang, 2001). Adolescents with internet addiction are more likely to have substance abuse experience. They stated that adolescents with high Internet addiction seek a higher rate of innovation and harm avoidance (Ko, Yen, Chen, Chen, Wu, \& Yen, 2006).

\section{Method}

\subsection{Research Question}

What is the relationship between social anxiety, internet addiction and alexithymia in adolescents? With the structural equation model. For this purpose, the research was carried out according to the relational screening 
model, which is a sub-type of the general screening model.

\subsection{Study Group}

The study consisted of 406 adolescents who attend different high schools in Beyşehir district of Konya, Turkey. The participants included 216 women (53.2\%) and 190 men (46.8\%). The age distribution included 131 aged $13-14$ (32.3\%), 178 aged 15-16 (43.8\%), and 97 aged 17-18 (23.9\%).

\subsection{Measures}

\subsubsection{Social Anxiety Scale for Adolescents (SAS-A)}

The social anxiety scale for adolescents consists of 22 items, four of which are unrelated. The scale consists of three factors. Supported by factor analysis, these sub-scales are Fear of Negative Evaluation (FNE), General Social Avoidance and Distress (SAD-G) and Social Avoidance and Distress in New Situations (SAD-N). Cronbach Alpha value of the sub-dimensions of the scale was found to be .86 for Fear of Negative Assessment, .82 for the sub-dimension of Fear in New Social Situations, .78 for the sub-dimension of Fear and Restlessness in the General Social Situations, and .95 for the whole scale. The correlation between the sub-dimensions of the scale varies between .61 and $0.64(\mathrm{p}<0.01)$ (Aydın \& Tekinsav-Sütçü, 2007). DFA analysis was conducted on the social anxiety scale on the study group. As a result of the CFA analysis, it was observed that the factor loads of the scale items ranged from .41 to .83 and each scale item was significant $\left(\mathrm{x}^{2}=\right.$ 4.11).

\subsubsection{Internet Addiction Scale (IAS)}

The scale consists of 35 items. The scale is rated as a five-point Likert type, ranging from 'strongly disagree' (1) to 'strongly agree' (5). As a result of the CFA analysis, it was observed that the factor loads of the scale items ranged from .41 to .83 and each scale item was significant $\left(\mathrm{x}^{2}=4.11\right)$. The average age of the participants is 15.8 Cronbach Alpha internal consistency coefficient of the scale was found to be 0.94 . The scale consists of 4 sub-factors. These are "Withdrawal", "Controlling difficulty", "Disorder in Functionality" and "Social Isolation". The total explained variance for its four sub-dimensions is $47.46 \%$. The high score obtained from the scale indicates internet addiction (Günüç \& Kayri, 2010). DFA analysis was carried on the scale of Internet addiction out on the study group. As a result of the CFA analysis, it was observed that the factor loads of the scale items ranged from .58 to .78 and each scale item was significant $\left(\mathrm{x}^{2}=3.55\right)$.

\subsubsection{Toronto Alexithymia Scale (TAS-20)}

The original form of the Twenty-question Toronto Alexithymia Scale (TAS-20) was developed by Bagby, Parker and Taylor et al. (1994) and adapted to Turkish by Gulec (2009). The internal reliability coefficient of the scale was calculated as 0.78 . And of the sub-scales were between $0.57-0.80$. TAÖ-20 is a Likert-type self-rating scale, scored between one (never agree) and five (always agree). Difficulty Identifying Feelings sub-scale consists of seven items and is defined as the difficulty in identifying emotions and distinguishing them from bodily sensations accompanying emotional arousal. Difficulty Describing Feelings sub-scale consists of five items and it is defined as difficulty in transferring emotions to others. Externally-Oriented Thinking sub-scale consists of eight items, and it is defined as the existence of an extroverted cognitive structure, the weakness of introverted thinking and imagination. Individuals are asked to mark the most appropriate one of the options of "Never", "Rarely", "Sometimes", "Often" and "Always" for each item. High scores indicate high alexithymic level (Güleç et al., 2009)

\subsubsection{Personal Information Form}

It was prepared by the researchers to determine the gender and age of the participants.

\subsection{Data Collection and Analysis}

For the purpose of collecting data; The Social Anxiety Scale for Adolescents (ESCO), "Internet Addiction Scale", "Toronto Alexithymia Scale" and "Personal Information Form" were applied to the participants determined by the appropriate sampling method. A total of 406 students were recruited through convenience sampling method. In the research, structural equation modelling analysis was done in order to test the relationship between the variables of adolescents' social anxiety, internet addiction and alexithymia through the structural equation model. Structural equation modelling analysis was carried out with the AMOS 19 Program. In addition, correlation analysis and frequency, percentage analysis were done with SPSS 20 data analysis program. 


\section{Results}

The model obtained includes three exogenus, social anxiety (FNE, SAS-NS, SAD-G) and seven endogenous (EOT, DDF, DIF, Withdrawal, Controlling, Disorder, Social) data. Each of the paths shown in the model was found statistically significant. The Bentler-Bonett normed fit index (NFI), The Tucker-Lewis coefficient fit index (TLI) and other fit indexes have shown that the model is very well compatible (Table 1). The bidirectional correlations between the endogenous data in the model each have high values and are statistically significant.

Table 1. Statistical values regarding the adaptation of the structural equation model

\begin{tabular}{llll}
\hline Measure & Good fit & Acceptable fit & Fit Index Values of the Model \\
\hline$\left(\mathrm{X}^{2} / \mathrm{sd}\right)$ & $\leq 3$ & $\leq 4-5$ & 2.32 \\
SRMR & $\leq 0.05$ & $0.06-0.08$ & 0.04 \\
RMSEA & $\leq 0.05$ & $0.06-0.08$ & 0.05 \\
NFI & $\geq 0.95$ & $0.94-0.90$ & 0.96 \\
IFI & $\geq 0.95$ & $0.94-0.90$ & 0.97 \\
CFI & $\geq 0.97$ & $\geq 0.95$ & 0.97 \\
GFI & $\geq 0.90$ & $0.89-0.85$ & 0.96 \\
AGFI & $\geq 0.90$ & $0.89-0.85$ & 0.94 \\
TLI & $\geq 0.95$ & $0.94-0.90$ & 0.96 \\
\hline
\end{tabular}

When the compliance values in Table 1 are examined, $\mathrm{X} 2 / \mathrm{sd}=2.32(71,905 / 31), \mathrm{SRMR}=0.04, \mathrm{RMSEA}=0.05$, $\mathrm{IFI}=0.97, \mathrm{NFI}=0.96, \mathrm{CFI}=0.97, \mathrm{GFI}=0.96, \mathrm{AGFI}=0.94$ and $\mathrm{TLI}=0.96$. In general, it is understood that the model has the desired level of fit. The model tested is shown in Figure 1.

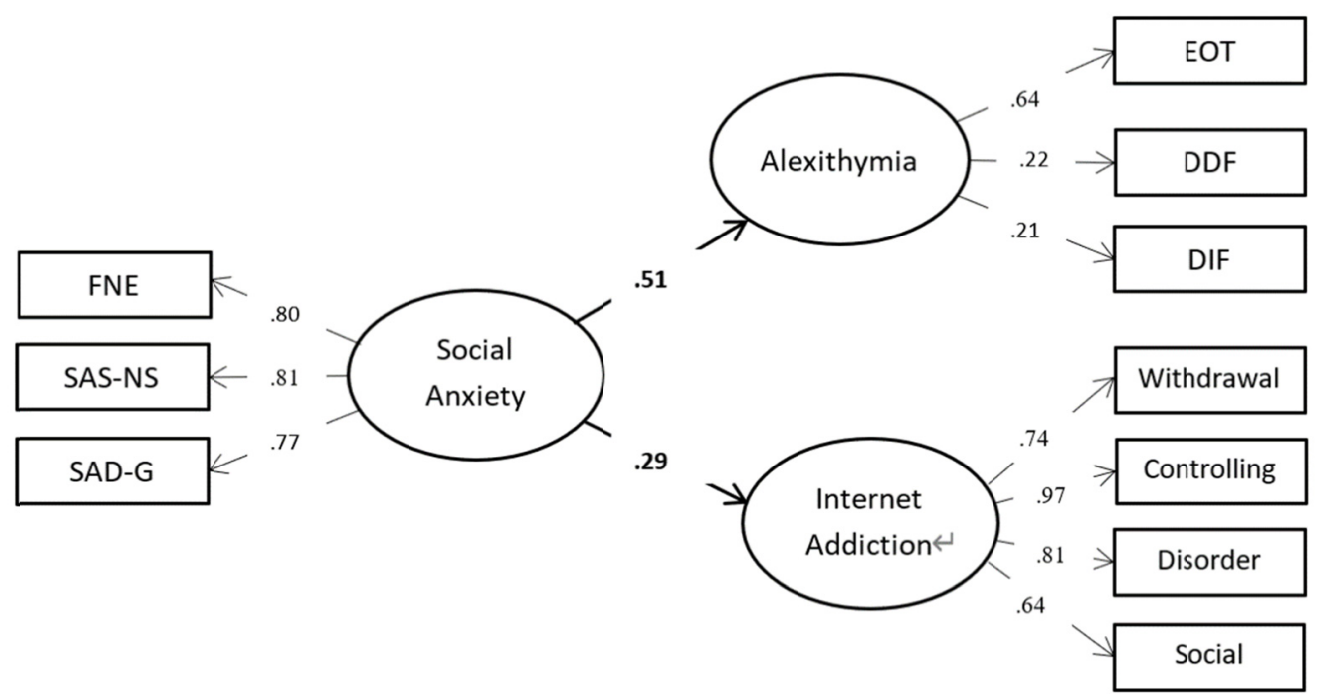

Figure 1. Path analysis related to the model

Table 2. Model for predictive relationships between social anxiety and internet addiction and alexithymia in adolescents

\begin{tabular}{llllll}
\hline Predictor Variable & Dependent Variable & Direct Effect & Standard Error & Critical Value & $\mathrm{p}$ \\
\hline Social Anxiety & Internet Addiction & .29 & 0.14 & 5.16 & $* * *$ \\
Social Anxiety & Alexithymia & .51 & 0.05 & 6.11 & $* * *$ \\
\hline
\end{tabular}

When the model in Figure 1 and the data in Table 2 are examined, it is seen that the social anxiety variable affects the internet addiction variable $(\mathrm{t}=5.16, \mathrm{p}<0.01)$. The connection coefficient value for this factor was determined as $\beta=0.29$. When the predictive relationships between adolescents' social anxiety and internet addiction variables were examined, it was determined that there was a positive linear relationship. In other words, findings reveal that as social anxiety level increases in adolescents, internet addiction will increase. 
When the model in Figure 1 and the data in Table 2 are examined, it is seen that the social anxiety variable affects the alexithymia variable $(\mathrm{t}=6.11, \mathrm{p}<0.01)$. The connection coefficient value for this factor was determined as $\beta=0.51$. When the predictive relationships between social anxiety and alexithymia variables were examined, it was determined that there was a positive linear relationship. In other words, findings reveal that as social anxiety level increases in adolescents, alexithymia will increase.

Table 3. Mean, standard deviation, reliability coefficient and correlations of variables

\begin{tabular}{lllllll}
\hline Variables & Mean & SD & $\alpha$ & Social Anxiety & Internet Addiction & Alexithymia \\
\hline Social Anxiety & 56.67 & 14.29 & .889 & - & & \\
Internet Addiction & 75.25 & 25.57 & .954 & $.227^{* *}$ & - & - \\
Alexithymia & 62.73 & 5.85 & .176 & $.293^{* *}$ & .055 & - \\
\hline
\end{tabular}

Note. ${ }^{* *} \mathrm{p}<.01 ; * \mathrm{p}<.05, \mathrm{~N}=406$.

The mean scores, standard deviations, and correlation values between the variables are presented in Table 3 . The findings show that social anxiety is significant and in the same direction with internet addiction $(r=.23, p<.01)$; social anxiety is significant and in the same direction with alexithymia $(\mathrm{r}=.29, \mathrm{p}<.01)$.

\section{Discussion}

In this part of the study, the findings obtained by examining the relationship between the social anxiety, internet addiction and alexithymia variables of the adolescents constituting the study group were discussed and discussed. When the predictive relationships of adolescents between social anxiety and internet addiction variables were examined, it was determined that there was a positive linear relationship. In other words, findings reveal that as adolescents increase social anxiety, internet addiction will increase.

Internet usage frequency has a negative effect on frequency of communication with others and social interaction (Nie, 2001). For example; social anxiety has also been shown to increase as adolescents use the internet (Harman, Hansen, Cochran, \& Lindsey, 2005). Socially anxious individuals may find it easier to interact online rather than face-to-face interactions where observation by others may have a fear of negative evaluation (Shepherd \& Edelmann, 2005). From this point of view, studies supporting the findings obtained in the research have been carried out. Lee and Stapinski (2012) found social anxiety as an important predictor of problematic internet use. In another study, social anxiety predicts problematic internet use (Weinstein \& Lejoyeux, 2010). In the model created for social anxiety and internet addiction for six Asian countries, the path from social anxiety to internet addiction; it fits well for Japan, South Korea and the Philippines (Lai et al., 2015). Weinstein, Dorani, Elhadif, Bukovza and Yarmulnik (2015) found a positive relationship between internet addiction and social anxiety in their study. Social anxiety is positively associated with problematic internet use (Cuhadar, 2012; Prizant-Passal, Shechner, \& Aderka, 2016). Huan, Ang and Chye (2014)'s results obtained revealed support for a model in which social anxiety fully mediated the relationship between the psychological variables of shyness and loneliness and problematic internet use. Fear-anxiety and depression were positively correlated with cognitive internet use cognitions among university students (Durak \& Senol-Durak, 2013). It has been found that students with internet addiction have higher social anxiety (Yucens \& Uzer, 2018). Anxiety has been found to positively predict internet addiction (Azher, Khan, Salim, Bilal, Hussain, \& Haseeb, 2014; Razieh, Ghasempoor, Ajdari, \& Sadeghigooghari, 2012).

High level of social anxiety is also associated with frequent internet use (Mazalin \& Moore, 2012). The internet may have good potential as an alternative tool to provide interventions for social anxiety (Yen, Yen, Chen, Wang, Chang, \& Ko, 2012) and also increased face-to-face contacts can help reduce symptoms of internet addiction (Yao \& Zhong, 2014).

When the predictive relationships between social anxiety and alexithymia were examined in adolescents, it was determined that there was a positive linear relationship. In other words, findings reveal that as adolescents increase their social anxiety level, alexithymia will increase. Alexithymic features emerge in close connection with difficulties in accepting their own feelings and social anxiety features (Edel et al., 2010). In addition, alexithymia is a common personality trait in Turkish patients with social anxiety disorders (Solmaz, Sayar, Ozer, Ozturk, \& Acar, 2000). There are studies supporting the findings obtained in this study. Kaur and Kaur (2015) was found that social anxiety was positively related to alexithymia in adolescents. Social anxiety symptoms are also significantly related to alexithymia in different samples (Evren \& Evren, 2007; Panayiotou, Leonidou, Constantinou, \& Michaelides, 2008). They found a positive relationship between anxiety and alexithymia 
(Berthoz, Consoli, Perez-Diaz, \& Jouvent, 1999; Fukunishi, Kikuchi, Wogan, \& Takubo, 1997; Karukivi et al., 2010; Nakao \& Takeuchi, 2018; Stewart, Zvolensky, \& Eifert, 2002). With an increase in anxiety complaints in alexithymic individuals, the "Difficulty in Defining Emotions" dimension increased (Motan \& Gencoz, 2007). Again, the "Difficulty in Defining Emotions" subscale was found to be associated with social anxiety (Suslow, 1998). The sub-dimension of anxiety and difficulty in recognizing emotions was associated (Evren, Evren, Dalbudak, \& Çakmak, 2008; Marchesi, Brusamonti, \& Maggini, 2000). As a result, internet addiction and alexithymic features may increase in socially anxious adolescents.

\section{References}

Aydın, A., \& Tekinsav-Sutcu, S. (2007). Validity and reliability of social anxiety scale for adolescents (SAS-A). Journal of Child and Youth Mental Health, 14(2), 79-89.

Azher, M., Khan, R. B., Salim, M., Bilal, M., Hussain, A., \& Haseeb, M. (2014). The Relationship between internet addiction and anxiety among students of University of Sargodha. International Journal of Humanities and Social Science, 4(1), 288-293.

Bagby, R. M., Parker, J. D. A., \& Taylor, G. J. (1994). The Twenty-item Toronto alexithymia scale-I. Item selection and cross validation of the factor structure. Journal of Psychosomatic Research, 38(1), 23-32. https://doi.org/10.1016/0022-3999(94)90005-1

Berthoz, S., Consoli, S., Perez-Diaz, F., \& Jouvent, R. (1999). Alexithymia and anxiety: compounded relationships? A Psychometric Study, 14(7), 372-378. https://doi.org/10.1016/S0924-9338(99)00233-3

Blanco, C., Bragdon, L. B., Schneier, F. R., \& Liebowitz, M. R. (2013). The evidence-based pharmacotherapy of social anxiety disorder. International Journal of Neuropsychopharmacology, 16, 235-249. https://doi.org/10.1017/S1461145712000119

Bögels, S. M., Alden, L., Beidel, D. C., Clark, L. A., Pine, D. S., Stein, M. B., \& Voncken, M. (2010). Social anxiety disorder: Questions and answers for the DSM-V. Depression and Anxiety, 27, 168-189. https://doi.org/10.1002/da.20670

Bruce, S. E., Yonkers, K. A., Otto, M. W., Eisen, J. L., Weisberg, R. B., Pagano, M., ... Keller, M. B. (2005). Influence of psychiatric comorbidity on recovery and recurrence in generalized anxiety disorder, social phobia, and panic disorder: A 12-year prospective study. American Journal of Psychiatry, 162(6), 11791187. https://doi.org/10.1176/appi.ajp.162.6.1179

Campanella, F., Shallice, T., Ius, T., Fabbro, F., \& Skrap, M. (2014). Impact of brain tumour location on emotion and personality: a voxel-based lesion-symptom mapping study on mentalization processes. Brain, 137, 2532-2545. https://doi.org/10.1093/brain/awu183

Campanella, S., Falbo, L., Rossignol, M., Grynberg, D., Balconi, M., Verbanck, P., \& Maurage, P. (2012). Sex differences on emotional processing are modulated by subclinical levels of alexithymia and depression: a preliminary assessment using event-related potentials. Psychiatry Research, 197, 145-153. https://doi.org/10.1016/j.psychres.2011.12.026

Cheng, C., \& Li, A. Y. (2014). Internet addiction prevalence and quality of (real) life: A meta-analysis of 31 nations across seven world regions. Cyberpsychology Behavior, and Social Networking, 17(12), 755-760. https://doi.org/10.1089/cyber.2014.0317

Chou, C., Condron, L., \& Belland, J. C. (2005). A review of the research on internet addiction. Educational Psychology Review, 17(4), 363-388. https://doi.org/10.1007/s10648-005-8138-1

Chou, C., \& Hsiao, M. C. (2000). Internet addiction, usage, gratification, and pleasure experience: the Taiwan college students' case. Computers \& Education, 35, 65-80. https://doi.org/10.1016/S0360-1315(00)00019-1

Conrad, R., Schilling, G., Langenbuch, M., Haidl, G., \& Liedtke, R. (2001). Alexithymia in male infertility. Human Reproduction, 16(3), 587-592. https://doi.org/10.1093/humrep/16.3.587

Cuhadar, C. (2012). Exploration of problematic Internet use and social interaction anxiety among Turkish $\begin{array}{lllll}\text { pre-service teachers. } \quad \text { Computers } \& \text { Education, } & \text { 59(2), } 181 .\end{array}$ https://doi.org/10.1016/j.compedu.2011.12.029

Dahl, R. E. (2004). Adolescent brain development: a period of vulnerabilities and opportunities. Keynote address. Annals of the New York Academy of Sciences, 1021, 1-22. https://doi.org/10.1196/annals.1308.001

Davis, R. A. (2001). A cognitive-behavioral model of pathological Internet use. Computers in Human Behavior, 


\section{7, 187-195. https://doi.org/10.1016/S0747-5632(00)00041-8}

Davis, R. A., Flett, G. L., \& Besser, A. (2002). Validation of a new scale for measuring problematicinternet use: implications for pre-employment screening. Cyberpsychology Behavior, 5(4), 331-345. https://doi.org/10.1089/109493102760275581

De Berardis, D., Serroni, N., Campanella, D., Carano, A., Gambi, F., Valchera, A., ... Ferro, F. M. (2008). Alexithymia and its relationships with C-reactive protein and serum lipid levels among drug naive adult outpatients with major depression. Progress in Neuropsychopharmacol Biological Psychiatry, 32(8), 19821986. https://doi.org/10.1016/j.pnpbp.2008.09.022

Donovan, C. L. (2014). Brief treatment of child social anxiety disorder. Psychopathology Review, 1(1), 195-200. https://doi.org/10.5127/pr.033513

Durak, M., \& Senol-Durak, E. (2013). Associations of social anxiety and depression with cognitions related to problematic internet use in youths. Education and Science, 38(169), 19-29.

Edel, M. A., Rudel, A., Hubert, C., Scheele, D., Brüne, M., Juckel, G., \& Assion, H. J. (2010). Alexithymia, emotion processing and social anxiety in adults with ADHD. European Journal of Medical Research, 15, 403-409. https://doi.org/10.1186/2047-783X-15-9-403

Eksi, A. (2003). Review: Youth issues on five continents. Journal of Child and Youth Mental Health, 10(2), 7887.

Erwin, P. (2000). Friendship in childhood and adolescence. Istanbul: Alfa Publishing.

Evren, B., \& Evren, C. (2007). Relationship between alexithymia and social anxiety in female outpatients with dermatological disorder presenting for psychiatric consultation. Journal of Clinical Psychology in Medical Settings, 14(3), 258-265. https://doi.org/10.1007/s10880-007-9072-9

Evren, C., Evren, B., Dalbudak, E., \& Cakmak, D. (2008). Alexithymia and personality in relation to social anxiety in male alcohol-dependent inpatients. Archives of Neuropsychiatry, 45, 72-77.

Franz, M., Popp, K., Schaefer, R., Wolfgang, S., Schneider, C., Hardt, J., ... Braehler, E. (2008). Alexithymia in the German general population. Social Psychiatry and Psychiatric Epidemiology, 43, 54-62. https://doi.org/10.1007/s00127-007-0265-1

Fukunishi, I., Kikuchi, M., Wogan, J., \& Takubo, M. (1997). Secondary alexithymia as a state reaction in panic disorder and social phobia. Comprehensive Psychiatry, 38(3), 166-170. https://doi.org/10.1016/S0010-440X(97)90070-5

Geenen, R., van Ooijen-van der Linden, L., Lumley, M. A., Bijlsma, J. W. J., \& van Middendorp, H. (2012). The match-mismatch model of emotion processing styles and emotion regulation strategies in fibromyalgia. Journal of Psychosomatic Research, 72, 45-50. https://doi.org/10.1016/j.jpsychores.2011.09.004

Gentile, D. (2009). Pathological video-game use among youth ages 8 to 18: A National Study. Psychological Science, 20(5), 594-602. https://doi.org/10.1111/j.1467-9280.2009.02340.x

Goerlich-Dobre, K. S., Witteman, J., Schiller, N. O., van Heuven, V. J. P., Aleman, A., \& Martens, S. (2014). Blunted feelings: Alexithymia is associated with a diminished neural response to speech prosody. Scan, 9, 1108-1117. https://doi.org/10.1093/scan/nst075

Gulec, H., Kose, S., Yazici-Gulec, M., Citak, S., Evren, C., Borckardt, J., \& Sayar, K. (2009). Reliability and Factorial Validity of the Turkish Version of the 20-Item Toronto Alexithymia Scale (TAS-20). Bulletin of Clinical Psychopharmacology, 19, 214-220.

Gunuc, S., \& Kayri, M. (2010). The profile of internet dependency in Turkey and development of internet addiction scale: Study of validity \& reliability. H. U. Journal of Education, 39, 220-232.

Harman, J. P., Hansen, C. E., Cochran, M. E., \& Lindsey, C. R. (2005). Liar, Liar: Internet faking but not frequency of use affects social skills, self-esteem. Social Anxiety and Aggression, 8(1), 1-6. https://doi.org/10.1089/cpb.2005.8.1

Hayward, C., Wilson, K. A., Lagle, K., Kraemer, H. C., Killen, J. D., \& Taylor, C. B. (2008). The developmental psychopathology of social anxiety in adolescents. Depression and Anxiety, 25, 200-206. https://doi.org/10.1002/da.20289

Huan, V. S., Ang, R. P., \& Chye, S. (2014). Loneliness and shyness in adolescent problematic internet users: The role of social anxiety. Child \& Youth Care Forum, 43(5), 539-551. 
https://doi.org/10.1007/s10566-014-9252-3

Karukivi, M., Hautala, L., Kaleva, O., Haapasalo-Pesu, K. M., Liuksila, P. R., Joukamaa, M., \& Saarijärvi, S. (2010). Alexithymia is associated with anxiety among adolescents. Journal of Affective Disorders, 125(1-3), 383-387. https://doi.org/10.1016/j.jad.2010.02.126

Kaur, H., \& Kaur, S. (2015). Social anxiety in relation to alexithymia among adolescents. Journal of Psychosocial Research, 10(2), 421-429.

Kessler, R. C., Chiu, W. T., Demler, O., \& Walters, E. E. (2005). Prevalence, severity, and comorbidity of twelve-month DSM-IV disorders in the National Comorbidity Survey Replication (NCS-R). Archives of General Psychiatry, 62(6), 617-627. https://doi.org/10.1001/archpsyc.62.6.617

Kessler, R. C., Stein, M. B., \& Berglund, P. (1998). Social phobia subtypes in the National Comorbidity Survey. American Journal of Psychiatry, 155(5), 613-619. https://doi.org/10.1176/ajp.155.5.613

Ko, C. H., Yen, J. Y., Chen, C. C., Chen, S. H., Wu, K., \& Yen, C. F. (2006). Tridimensional personality of adolescents with internet addiction and substance use experience. The Canadian Journal of Psychiatry, 51(14), 887-894. https://doi.org/10.1177/070674370605101404

Kulaksizoglu, A. (2004). Adolescent psychology (6th ed.). Istanbul: Remzi Publishing.

Kuss, D. J., \& Griffiths, M. D. (2012). Internet and gaming addiction: A systematic literature review of neuroimaging studies. Brain Sciences, 2, 347-374. https://doi.org/10.3390/brainsci2030347

La Greca, A. M., \& Lopez, N. (1998). Social anxiety among adolescents: Linkages with peer relations and friendships. Journal of Abnormal Child Psychology, 26(2), 83-94. https://doi.org/10.1023/A:1022684520514

Lai, C. M., Mak, K. K., Watanabe, H., Jeong, J., Kim, D., Bahar, N., ... Cheng, C. (2015). The mediating role of Internet addiction in depression, social anxiety, and psychosocial well-being among adolescents in six Asian countries: a structural equation modelling approach. Public Health, 129(9), 1224-1236. https://doi.org/10.1016/j.puhe.2015.07.031

Lane, R. D., Sechrest, L., Riedel, R., Shapiro, D. E., \& Kaszniak, A. W. (2000). Pervasive emotion recognition deficit common to alexithymia and the repressive coping style. Psychosomatic Medicine, 62, 492-501. https://doi.org/10.1097/00006842-200007000-00007

Lee, B. W., \& Stapinski, L. A. (2012). Seeking safety on the internet: Relationship between social anxiety and problematic internet use. Journal of Anxiety Disorders, 26(1), 197-205 https://doi.org/10.1016/j.janxdis.2011.11.001

Lesser, I. M. (1981). A review of the alexithymia concept. Psychosomatic Medicine, 43(6), 531-543. https://doi.org/10.1097/00006842-198112000-00009

Liu, F. (2010). The Internet in the everyday life - world: a comparison between high - school students in China and Norway. Comparative Education, 46(4), 527-550, https://doi.org/10.1080/03050068.2010.519483

Lumley, M. A. (2004). Alexithymia, emotional disclosure, and health: A program of research. Journal of Personality, 72(6), 1271-1300. https://doi.org/10.1111/j.1467-6494.2004.00297.x

Lumley, M. A., Neely, L. C., \& Burger, A. J. (2007). The Assessment of alexithymia in medical settings: Implications for understanding and treating health problems. Journal of Personality Assessment, 89(3), 230-246, https://doi.org/10.1080/00223890701629698

Marchesi, C., Brusamonti, E., \& Maggini, C. (2000). Are alexithymia, depression, and anxiety distinct constructs in affective disorders? Journal of Psychosomatic Research, 49(1), 43-49. https://doi.org/10.1016/S0022-3999(00)00084-2

Mazalin, D., \& Moore, S. (2012). Internet use, identity development and social anxiety among young adults. Behaviour Change, 21(2), 90-102. https://doi.org/10.1375/bech.21.2.90.55425

Moll, M. (2003). Computers and kids: Pulling the plug can protect the planet. The Phi Delta Kappan, 84(8), 600-602. https://doi.org/10.1177/003172170308400812

Moriguchi, Y., Ohnishi, T., Decety, J., Hirakata, M., Maeda, M., Matsuda, H., \& Komaki, G. (2009). The human mirror neuron system in a population with deficient self-awareness: An fMRI study in alexithymia. Human Brain Mapping, 30, 2063-2076. https://doi.org/10.1002/hbm.20653

Morrison, A. S., \& Heimberg, R. G. (2013). Social anxiety and social anxiety disorder. Annu. Rev. Clin. Psychol., 
9, 249-274. https://doi.org/10.1146/annurev-clinpsy-050212-185631

Motan, İ., \& Gencoz, T. (2007). The Relationship between the dimensions of alexithymia and the intensity of depression and anxiety. Turkish Journal of Psychiatry, 18(4), 333-343.

Nemiah, J. C. (1977). Alexithymia. Theoretical considerations. Psychother Psychosom, 28, 199-206. https://doi.org/10.1159/000287064

Nie, N. H. (2001). Sociability, interpersonal relations, and the Internet: Reconciliating conflicting findings. The American Behavioral Scientist, 45(3), 420-435. https://doi.org/10.1177/00027640121957277

Norris, M. L. (2007). HEADSS up: Adolescents and the internet. Paediatr Child Health, 12(3), 211-216. https://doi.org/10.1093/pch/12.3.211

O'Reilly, M. (1996). Internet addiction: a new disorder enters the medical lexicon. Can Med Assoc J., 154, 1882-1883.

O’Toole, M. S., Hougaard, E., \& Mennin, D. S. (2013). Social anxiety and emotion knowledge: A meta-analysis. Journal of Anxiety Disorders, 27(1), 98-108. https://doi.org/10.1016/j.janxdis.2012.09.005

Orvin, G. H. (1997). Ways to understand your adolescent child. Ankara: HYB Publishing.

Panayiotou, G., Leonidou, C., Constantinou, E., \& Michaelides, M. P. (2008). Self-Awareness in alexithymia and associations with social anxiety. Current Psychology. https://doi.org/10.1007/s12144-018-9855-1

Prizant-Passal, S., Shechner, T., \& Aderka, I. M. (2016). Social anxiety and internet use-A meta-analysis: What do we know? What are we missing? Computers in Human Behavior, 62, 221-229. https://doi.org/10.1016/j.chb.2016.04.003

Razieh, J., Ghasempoor, A., Ajdari, Z., \& Sadeghigooghari, N. (2012). The relationship between internet addiction and anxiety in the universities students. Interdisciplinary Journal of Contemporary Research in Business, 4(1), 942-949.

Ricciardi, L., Demartini, B., Fotopoulou, A., \& Edwards, M. J. (2015). Alexithymia in Neurological Disease: A $\begin{array}{lllll}\text { Review. } J \text { Neuropsychiatry } & \text { Clin }\end{array}$ https://doi.org/10.1176/appi.neuropsych.14070169

Sasmaz, T., Oner, S., Kurt, A. O., Yapici, G., Ertekin-Yazici, A., Bugdayci, R., \& Sis, M. (2013). Prevalence and risk factors of Internet addiction in high school students. European Journal of Public Health, 24(1), 15 20. https://doi.org/10.1093/eurpub/ckt051

Sato, T. (2006). Internet addiction among student: Prevalence and psychological problems in Japan. Clinical Topics in Japan, 49(7-8), 279-283.

Schlenker, B. R., \& Leary, M. R. (1982). Social anxiety and self-presentation: a conceptualization and model. Psychological Bulletin, 92(3), 641-669. https://doi.org/10.1037/0033-2909.92.3.641

Shapira, N. A., Lessig, M. C., Goldsmith, T. D., Szabo, S. T., Lazoritz, M., Gold, M. S., \& Stein, D. J. (2003). Problematic internet use: Proposed classification and diagnostic criteria. Depression and Anxiety, 17(4), 207-216. https://doi.org/10.1002/da.10094

Shepherd, R. M., \& Edelmann, R. J. (2005). Reasons for internet use and social anxiety. Personality and Individual Differences, 39(5), 949-958. https://doi.org/10.1016/j.paid.2005.04.001

Sifneos, P. E. (2000). Alexithymia, clinical issues, politics and crime. Psychotherapy and Psychosomatics, 69 , 113-116. https://doi.org/10.1159/000012377

Solmaz, M., Sayar, K., Ozer, A., Ozturk, M., \& Acar, B. (2000). Alexithymia, hopelessness and depression in social phobic patients: A study with a control group. J. Clin Psy, 3(4), 235-241.

Speranza, M., Loas, G., Wallier, J., \& Corcos, M. (2007). Predictive value of alexithymia in patients with eating disorders: A 3-year prospective study. Journal of Psychosomatic Research, 63, 365-371. https://doi.org/10.1016/j.jpsychores.2007.03.008

Stewart, S. H., Zvolensky, M. J., \& Eifert, G. H. (2002). The relations of anxiety sensitivity, experiential avoidance, and alexithymic coping to young adults' motivations for drinking. Behavior Modification, 26(2), 274-296. https://doi.org/10.1177/0145445502026002007

Suslow, T. (1998). Alexithymia and automatic affective processing. European Journal of Personality, 12(6), 433-443. https://doi.org/10.1002/(SICI)1099-0984(199811/12)12:6<433::AID-PER320>3.0.CO;2-O 
Taylor, G. J. (2000). Recent developments in alexithymia theory and research. Can. J. Psychiatry, 45, 134-142. https://doi.org/10.1177/070674370004500203

Taylor, G. J., \& Bagby, R. M. (2012). The alexithymia personality dimension. In T. A. Widiger (Ed.), Oxford library of psychology. The Oxford handbook of personality disorders (pp. 648-673). Oxford University Press. https://doi.org/10.1093/oxfordhb/9780199735013.013.0030

Temel, Z. F., \& Aksoy, A. B. (2001). Adolescent and his development the first step to adulthood. Ankara: Nobel Publishing.

Turkle, S. (1996). Virtuality and its discontents: Searching for community in cyberspace. The American Prospect, $24,50-57$.

Vanheule, S., Desmet, M., \& Meganck, R. (2007). Alexithymia and interpersonal problems. Journal of Clinical Psychology, 63(1), 109-117. https://doi.org/10.1002/jclp.20324

Vorst, H. C. M., \& Bermond, B. (2001). Validity and reliability of the Bermond-Vorst Alexithymia Questionnaire. Personality and Individual Differences, 30, 413-434. https://doi.org/10.1016/S0191-8869(00)00033-7

Weinstein, A., Dorani, D., Elhadif, R., Bukovza, Y., \& Yarmulnik, A. (2015). Internet addiction is associated with social anxiety in young adults. Annals of Clinical Psychiatry, 27(1), 2-7.

Weinstein, A., \& Lejoyeux, M. (2010). Internet addiction or excessive internet use. The American Journal of Drug and Alcohol Abuse, 36(5), 277-283. https://doi.org/10.3109/00952990.2010.491880

Wittchen, H. U., \& Fehm, L. (2003). Epidemiology and natural course of social fears and social phobia. Acta $\begin{array}{llll}\text { Psychiatrica } & \text { Scandinavica } & \text { Supplementum, } & \text { 108(417), }\end{array}$ https://doi.org/10.1034/j.1600-0447.108.s417.1.x

Yang, C. K. (2001). Sociopsychiatric characteristics of adolescents who use computers to excess. Acta Psychiatr Scand, 104(3), 217-222. https://doi.org/10.1034/j.1600-0447.2001.00197.x

Yao, M. Z., \& Zhong, Z. J. (2014). Loneliness, social contacts and Internet addiction: A cross-lagged panel study. Computers in Human Behavior, 30, 164-170. https://doi.org/10.1016/j.chb.2013.08.007

Yen, J. Y., Yen, C. F., Chen, C. S., Wang, P. W., Chang, Y. H., \& Ko, C. H. (2012). Social anxiety in online and real-life interaction and their associated factors. Cyberpsychology, Behavior, and Social Networking, 15(1), 7-12. https://doi.org/10.1089/cyber.2011.0015

Young, K. S. (1996). Internet addiction: The emergence of a new clinical disorder. Paper presented at the 104th annual meeting of the American Psychological Association, Toronto, Canada, August 15, 1996.

Young, K. S. (2004). Internet addiction. American Behavioral Scientist, 48(4), 402-415. https://doi.org/10.1177/0002764204270278

Yorukoglu, A. (2006). Child mental health (28th ed.). Istanbul: Ozgur Publishing.

Yücens, B., \& Üzer, A. (2018). The relationship between internet addiction, social anxiety, impulsivity, self-esteem, and depression in a sample of Turkish undergraduate medical students. Psychiatry Research, 267, 313-318. https://doi.org/10.1016/j.psychres.2018.06.033

\section{Copyrights}

Copyright for this article is retained by the author, with first publication rights granted to the journal.

This is an open-access article distributed under the terms and conditions of the Creative Commons Attribution license (http://creativecommons.org/licenses/by/4.0/). 